\title{
An Analysis of Violation and Flouting Maxim on Teacher- Students Interaction in English Teaching and Learning Process
}

\author{
Siti Arofah ${ }^{1}$ \\ Husni Mubarok ${ }^{2}$ \\ husni@unisnu.ac.id \\ ${ }^{1,2}$ Universitas Islam Nahdlatul Ulama Jepara, Indonesia
}

\begin{abstract}
The objectives of this research are to analyze the type of violation and flouting the maxim of teacherstudent interaction in the English teaching and learning process in MA Hasyim Asy'ari Bangsri and also find the most frequently produced between violation and flouting of the maxim. This research used the descriptive qualitative method. The data was obtained from the conversation between the teacher and students during the teaching and learning process and analyzed by categorizing utterances based on the violation and flouting maxim theory of the Cooperative Principle. The data were collected through the observation then analyzed by using the technique which is suggested by Miles and Huberman that consists of data reduction, data display, and drawing conclusion or data verification. The result of the research showed that there are four types of maxims that are violated by the teacher and students. These are the maxim of quantity $11(50 \%)$, the maxim of quality $5(22.73 \%)$, the maxim of relation $1(4.54 \%)$, and the maxim of manner $5(22.73 \%)$. The dominant violation was the maxim of quantity with 11 occurrences. Based on the findings, there are three types of flouting maxims in which the most of flouting maxim that is occurred was the maxim of relation. They are divided into $1(14.29 \%)$ maxim of quantity, 2 (28.57\%) maxim of quality, and $4(57.14 \%)$ maxims of relation. In conclusion, the most produced between the violation and flouting was the violation of maxim with $22(75.86 \%)$ of total occurrences. Meanwhile, the proportion of flouting maxim was 7 (24.14\%).
\end{abstract}

Keywords: Maxims, descriptive qualitative, cooperative principle, teacher-students interaction

\section{INTRODUCTION}

Language is a device of communication for people. It is an important role in human development and history as a main tool of interaction. Through the presence of language, people can share any information, facts, or ideas among others. Moreover, people can also express their feelings through language. In conversations, sometimes, the interlocutor wants the hearer to find the hidden meaning or implicit meaning of the utterances. Yule (1996, p. 35) said that speakers actually communicate more than the words they utter, in this case, they communicate the additional meaning to the hearer. This study is called implicature. Sihai (2008, p.10) defines implicature as a special case of situations in which the perceived meaning extends beyond the literal meaning.
The use of language for expression is expected to obey the maxim of the cooperative principle proposed by Grice (1975), this is required for the communication to be run well and effectively. Pragmatic provides Cooperative Principle theory which encourages people to be cooperative in communicating toward each other. Grice (2004, p. 45) also states Cooperative Principle is to make your conversational contribution what is required; at the stage at which it occurs, by the accepted purpose or direction of the talk exchange in which you are engaged.

The cooperative principle of conversation is elaborated in four sub-principles, called maxims. The four maxims are quantity, quality, relation, and manner. The maxim of quantity means the speaker should be as informative as required, they should give neither too little information nor too 
much. When they provide inadequate information, the interlocutor will not be able to identify what they are talking about because they do not give more information. On the other hand, those who give excessive information tend to imply something. Moreover, Grice (2004) stated that over informative is not the transgression of cooperative principle but merely either a waste of time or make confusion.

The maxim of quality concerns the truthfulness in an utterance. The interlocutor should not give information that he/she does not have evidence. Rahmi \& Wahyuni (2018, p. 177) argued that maxim of quality refers to the truth contribution given by the speaker in the conversation. This means that in following the maxim of quality, people should give information truthfully and provide evidence of it. Maxim of relation means is relevant. The interlocutor should say what is relevant to the conversation. In fulfilling the maxim of relation, people should adhere to the topic of the conversation. In addition, Dwi $(2015$, p. 246) explained that the maxim of relation must be relevant to the topic being conversed. The speaker and hearer must always ensure of what they say is the information that relates to the topic of conversation. Meanwhile, in fulfilling the maxim of manner, the interlocutor should give information as clearly and orderly as possible. Shofwan (2018, p. 75) explains that maxim of manner is to mean participants in discourse should not make their contributions obscure, ambiguous, or difficult to understand. Moreover, Zebua (2017, p. 104) defines maxim of manner as the speaker should be brief and orderly.

Sometimes people do not always follow the rule of the maxim in their interaction so that the communication is not efficient. Uncooperative communication is also found in the teaching and learning process. The speakers who do not obey the rule of the maxim are known as the violation and flouting maxim. Cutting (2002, p. 40) states a speaker can be said to 'violate' a maxim when they know that the hearer will not know the truth and will only understand the surface meaning of the words.
According to Elizabeth Black (2006) as cited in (Rahman \& Abbas, 2013, p. 54), flouting occurs when the speaker makes it clear to the hearer that he/she is aware of the cooperative principle and the maxims, that it makes the audience is led to consider why the principle or the maxim was broken. In flouting the maxim, the speakers employ the implicature. They expect the hearer to uncover the hidden meaning behind the utterance.

This present research investigated the violation and flouting maxims in teacher and student interaction during the English teaching and learning process at MA Hasyim Asy'ari Bangsri. The purposes of the research are to investigate the violation and flouting maxims that happen in classroom interaction during the English teaching and learning process. Another purpose was to find the most dominant type of violation and flouting and what most produced between the violation and flouting of the maxim.

\section{METHODOLOGY}

This research was descriptive qualitative research. The qualitative method is a method in which the researcher collects and analyses the data then draw the conclusion. Gerring (2007) states that descriptive qualitative research is a natural setting as the direct source of data with the researcher taking the role of being the key instrument. In conducting this research, the researcher did the observation in the teaching and learning process to obtain the data. In the observation, the researcher joined the group class in the online course. This research was conducted on $8-23$ October 2020 in three meetings.

The subjects of the research were a teacher and students of MA Hasyim Asy'ari Bangsri. The primary subjects were a teacher (a female teacher) and 26 students (2 males and 24 females). The students were 12th-grade Immersion students of MA Hasyim Asy'ari Bangsri in the academic year of 2020/2021. The data in this research were collected through virtual observation during the teaching and learning process. The data were in form of visual e.g. text message conversation and 
audio e.g. voice recording. In collecting the data, the researcher did some procedures as follows:

(1) The researcher listened to the utterances that were produced by the teacher and students, the researcher also read the utterances in the conversation during the teaching and learning process. Then the researcher tried to understand the utterances which were uttered by the teacher and students during the teaching and learning process.

(2) The researcher transcribed the audio recording of the utterances into writing form and also rewrote the utterances. The data which were transcribed were in form of a dialogue between teacher and students.

(3) The researcher listened to the recording several times to make sure that the data are accurate.

(4) The researcher classified the data into each type of violation and flouting maxim based on Grice's cooperative principle. Then gave a code. The researcher specified the types of violation and flouting of maxim and its number of occurrences.

The data were analyzed by using the technique which is suggested by Miles and Huberman. According to Miles \& Huberman (1994, p. 10), there are three activities in analyzing the data, namely data reduction, data display, and drawing conclusion or verification. In data reduction, the researcher reduced the data through selection. The researcher selected some parts of utterances which maxims that were violated and flouted based on the Cooperative Principles theory. After that, the researcher analyzed the type of violating and flouting maxims that occurred in the dialogue between teacher and students.

After reducing the data, in data display, the researcher displayed the data taken from the observation by presenting it in form of a table and descriptions. Then, the researcher calculated the percentage of violation and flouting maxim and decided what most produced between the violation and flouting maxim that found on teacher and students interaction in the classroom of their utterances. The formula which was used to know the frequency of the violation and flouting maxim as follow:

Explanation:

P: Percentage of a particular type of maxim (violation or flouting)

$\mathrm{N}$ : frequency of the particular type of maxim (violation or flouting)

T: Number of type of maxim (violation or flouting

To conclude the result, the data which were inserted as in the data display was confirmed to reach the trustworthiness of the data. Denzim (1970) in Cohen et al. (2000) states that there are several types of triangulation, they are time triangulation (to include diachronic reliability, stability over time and synchronic reliability, the similarity of data gathered at the same time), space triangulation, combined levels of triangulation (e.g. individual, group, organization, societal), theoretical triangulation (drawing on alternative theories), investigator triangulation (more than one observer), and methodological triangulation (using the same method on different occasions) or the researcher's techniques in collecting the data to obtain validation.

In this research, the researcher used methodological triangulation to reach the validation of data. Verification is enhanced by conducting through consultation with the expert. In addition, in getting the data trustworthiness, the researcher applied investigator triangulation. The researcher checked the data that was obtained from the observation to the expert. The researcher first classified the data of the cooperative principle of maxims that are obtained from the observation. Then the researcher consulted it to the expert of pragmatics study.

\section{RESULT AND DISCUSSION}

The Violation of Maxims That are Produced by The Teacher and Students in English Teaching and Learning Process

\section{Violation of Maxim Quantity}


Speaker violates the maxims of quantity when the information they give to the hearer is not enough to know what is being talked about. Here, the speaker does not want the hearer to know about the whole information. The example of violation maxim of quantity as follows:

(1) T: Download the pdf then see the question for compulsory English no 1 to 10. Any question?

S: Ditulis di buku atau gimana?

S: Ndak gitu mbak

S: Trus gimana fer?

S: Kamu buka pdf itu trus liat soal nah kalo ada yang ndak paham kamu tanyakan ke miss Risa.

S: Oh iya. Ga faham tadi.

S: Itu kan hari ini kita bahas soal yang mid kemarin. Kan miss Risa mau ngadain remidi. Nah sebelum kalian remidi kita bahas dulu soal-soalnya. Nah, pdf yang miss Risa kirimkan itu diliat,dari nomer yang miss Risa kasih tau mana nanti miss Risa terangkan.

From the conversation above, there were 2 violations of the maxim. The utterance, "Ndak gitu mbak," was not enough information. It can be seen from the utterance of, "Trus gimana fer?" which showed that the student did not fully understand the explanation. It indicates the violation maxim of quantity because the student gave too little information. Another violation of maxim quantity, could be seen in the utterance of, "Itu kan hari ini kita bahas soal yang mid kemarin. Kan miss Risa mau ngadain remidi. Nah sebelum kalian remidi kita bahas dulu soal-soalnya..." The teacher gave too much information than is required. It is enough for the teacher to answer by, "Nah, pdf yang miss Risa kirimkan itu diliat, dari nomer yang miss Risa kasih tau mana nanti miss Risa terangkan."

\section{Violation of Maxim Quality}

Noertjahjo et al. (2017, p. 178) explain that violating towards maxim of quality is a situation where a speaker is not sincere and gives wrong information to a hearer, which can be said as a lie.
(2) T: There are more or less still 8 students who haven't joined the class. Where are your friends?

S: I don't know miss. Mungkin makan atau mandi.

S: They are still walking in their sweet dreams.

S: Maybe still sleep or do something or help their mother. Idk.

In this conversation, the students' responses were seemingly untrue which were classified as a violation of maxim quality. The students violated the maxim of quality because she said something that she does not believe to be true. They did the violation of maxim quality twice. They gave the information with lack of evidence, as in the utterances of "I don't know miss. Mungkin makan atau mandi," and "Maybe still sleep or do something or help their mother. Idk."

\section{Violation of Maxim Relation}

Cutting (2002, p. 40) states that violating in the maxim of relation happens when speakers try to distract and change the topic to another one. Like the example below:

(3) $\mathrm{T}$ : Download the pdf then see the question for compulsory English no 1 to 10. Any question?

S: Ditulis di buku atau gimana?

From the conversation above, there was a violation of maxim relation. The teacher asked students if they have questions but then the student replayed, "Ditulis di buku atau gimana?" the utterance doesn't relate to the question of "Download the pdf then see the question for compulsory English no 1 to 10. Any question?" The questions could be replayed by using the word, "yes" or "no" such as, "Yes, I have question."

\section{Violation of Maxim Manner}

Cutting (2002) defines that violating towards maxim of manner happens when someone gives obscure reference, and vague reference, in order to avoid a brief and orderly answer in a conversation.

T: Compulsory English (the teacher was giving the score of Compulsory English) 
Optional English (the teacher was giving the score of Compulsory English)

S: MTDDS

T: What's that?

The word of MTDDS indicates as the violation of maxim manner. The student used the ambiguous word of MTDDS which it only could be understood by their friends who are in boarding school. It means only a few people know about the word. The following dialogue explains that the word of MTDDS is an abbreviation of the phrase Mak Tratap Dek-dek Ser. It is included as slang words. Slang words are specific words used by a particular group of people. MTDDS has a similar meaning to the word of nervous. The student was nervous to know their score he was actually afraid whether the score was bad. Instead of saying he was nervous or was not ready to know their score, the student failed to follow the maxim of manner by saying an ambiguous word.

Based on the observation during the teaching and learning process, the researcher found there are 22 violations of the maxim that are produced by the teacher and students on their interaction during the teaching and learning process. There are divided into violation of maxim quantity $11(50 \%)$, violations maxim of quality 5 $(22.73 \%)$, violation of maxim relation $1(4.54 \%)$, and violations of maxim manner 5 (22.73\%). There were 6 violations of maxim done by the teacher, while the students violated the maxims 16 times. It can be claimed that the students mostly did the violations of maxim rather than the teacher. The conclusion is the violation maxim of quantity was more dominantly violated. It occurred 11 times. This means the speakers tend to give too much information either less than what is required.

The Flouting Maxims That are Produced by The Teacher and Students in English Teaching and Learning Process

Aisya \& Fitrawati (2019, p. 43) argue that when speakers flout the maxim, it means that they are also being indirect in communication. In this research, there are 3 types of flouting maxim which was produced by the teacher and student in the teaching and learning process. The result consists of 1 (14.29\%) flouting maxim quantity, 2 (28.57\%) flouting maxims of quality, and 4 (57.14\%) flouting maxims of relation. None of the floutings of the maxim of manner was found. The data analysis can be seen as follows:

\section{Flouting Maxim of Quantity}

The speaker who breaks the maxim of quantity seems to give too little or too much information in which the speakers employ implicature.

(5) S: I forgot the result. Please, would you send it again.

T: Oh my god, you can scroll up.

Based on the conversation above, the teacher didn't give the information which was needed by the student. Instead of sending the score to the group, the teacher said, "Oh my god, you can scroll up," which implied that she didn't want to send it again, and asked the student to look for the score by scrolling up. Here, the teacher flouted the maxim of quantity because she didn't give the information what is required.

\section{Flouting Maxim of Quality}

Cutting (2002) stated that flouting the maxim of quality would imply a metaphorical use of language, an exaggerated expression of feelings (hyperbole), metaphor, irony, or banter. Irony and banter together form a pair. The example below:

$$
\begin{aligned}
& \text { S: Miss bahasa inggrisnya ambyar nopo kak? } \\
& \text { S: Im pyar. }
\end{aligned}
$$

Based on the conversation above, the flouting maxim of quality occurred because the student said that was blatantly untrue in which he lacked evidence about the English word of "ambyar". The word "Im pyar" was untrue. It implied that she didn't know how to say "ambyar" in English and tried to make a joke.

\section{Flouting Maxim of Relation}

According to Rahman \& Abbas (2013: 54), the maxim of relation is flouted when the speaker does not make the connection between his words 
and the context clear in a verbal manner. The speaker expects the hearer to understand what the utterance did not say through 'implicature'.

(7) T: Have you done reading the material?

S: Masih loading miss.

The teacher gave the material on-site by online learning. She asked the students to read the material first and asked them to give some questions that are related to the material.

According to the conversation above, the student flouted the maxim of relation by saying, "Masih loading miss." This has no relation to the question. The teacher's question could be answered by "No, I haven't done" or "Yes, I have done." The utterance of, "Masih loading miss" implied that the student hasn't started to read the material.

\section{The Violation and Flouting Maxim Happened during Teaching and Learning Process}

The total utterances of the violation maxims which were produced by the teacher and students were 22 data that were obtained from teacher and students interaction. There are $11(50 \%)$ utterances considered as the violation maxims of quantity. In this case, the teacher did the violation of maxim quantity more than the students. The teacher tended to give more information than is required. The teacher broke the rule of the maxim of quantity in order to make the student more understand about the material by giving

\section{Table 1}

The Violation and Flouting Maxim additional information. There were 5 (22.73\%) of violation maxims of quality. According to Cutting (2002), people who violate the maxim of quality indicates not being sincere and give wrong information. Based on the data analysis, the students violated the maxim of quality by giving wrong information in which it did not have evidence of it. Moreover, the students did more the violation of maxim of quality than the teacher. There were $1(4.54 \%)$ violation maxims of relation and the least, there were $5(22.73 \%)$ of the violations of maxim manner which are found during the teaching and learning process. In conclusion, the most violated maxim of cooperative principle that done by the teacher and student was the maxim of quantity.

The flouting maxims also occurred during the teaching and learning process. There were 7 occurrences of the flouting maxim in teacher and students' interaction. The researcher found three kinds of the maxim that were flouted by the teacher and students; they were the maxim of quantity $(14.29 \%)$, the maxim of quality $(28.57 \%)$, and the maxim of relation $(57.14 \%)$. The most flouted maxim was the maxim of relation that was done by the students. They flouted the maxim of relation by giving the information that did not have relation to the question. The students flouted the cooperative principle because want the hearer to uncover the hidden meaning behind the utterances.

\begin{tabular}{llll}
\hline No. & Non-observance Maxim & Frequency & Percentage \\
\hline 1. & The violation of Maxims & 22 & $75.86 \%$ \\
\hline 2. & The flouting of Maxims & 7 & $24.14 \%$ \\
\hline & Total & $\mathbf{2 9}$ & $\mathbf{1 0 0 \%}$ \\
\hline & Answering the problem & question, & CONCLUSION
\end{tabular}

according to the data table above, there were 22 $(75.86 \%)$ occurrences of the violation of maxim and $7(24.14 \%)$ occurrences of the flouting of maxim. Therefore, violation of maxims was the most frequently produced by teacher and students in their interaction during teaching and learning process.
This research was aimed to find the types of violation and flouting maxim of Cooperative principle and find the most frequently produced between violation and flouting of the maxim in teacher-student interaction during teaching and learning process in MA Hasyim Asy'ari Bangsri. Based on the data finding and discussion, it can be 
concluded that this research tried to employ the theory proposed by Grice (1974). The focus of the research was to analyze the violation of maxims and the flouting maxim based on Grice's cooperative principle maxims that were produced by the teacher and student in the teaching and learning process. According to the data analysis, there were 22 data $(75.86 \%)$ found considered as a violation of maxims, and 7 data $(24.14 \%)$ found included as the flouting maxims. It can be concluded that the violation of maxims is more dominating rather than the flouting maxims.

\section{REFERENCES}

Aisya, N., \& Fitrawati (2019). An analysis of flouting of maxim performed by politician guests in Mata Najwa talk show in the episode of adu lantang jelang penentuan and babak. E-Journal of Enlish Language and Literature, 8(4).

Cohen, L., Manion, L., Morrison, \& Keith. (2000). Research Methods in Education (5th ed.). Routledge.

Cutting, J. (2002). Pragmatics and Discourse. Routledge.

Dwi, A. E. (2015). An analysis of flouting maxim in EFL classroom interaction. Journal for Language and Foreign Language Learning. 4(2). 243-259.

Gerring, J. (2007). Case Study Research: Principles and Practices. Cambridge University Press.
Grice, H. P. (2004). Logic and Conversation. University of California.

Miles, M. B., \& Huberman, A. M. (1994). Qualitative Data Analysis (2nd ed). Sage Publications.

Noertjahjo, E., Arifin, M. B., \& Ariani, S. (2017). Analysis of flouting and violating towards maxim of quality in My Sister ' $S$ Keeper novel. Jurnal Ilmu Budaya, 1(3), 193-206.

Rahman, R., \& Abbas, S. (2013). Antic disposition: Hamlet in the light of cooperative principle. Journal of Humanities and Social Sciences, 21(1), 51-61.

Rahmi, S. S., Refnaldi, \& Wahyuni, D. (2018). The violation of conversational maxims found in political conversation at Rosi Talkshow. EJournal of Enlish Language and Literature. 7(1).

Shofwan, M. I. (2018). The violation of maxim rules in ketoprak humor. Journal of English Studies, 1(1), 72-81.

Sihai, W. (2008). Study on Teaching the interpretations of conversational implicaturein listening comprehension. CELEA Journal. 31 (3). 66 - 77.

Yule, G. (1996). Pragmatics. Oxford University Press.

Zebua, E. Rukmini, D., \& Saleh, M. (2017). The violation and flouting of cooperative principles in the Ellen Degeneres talk show. Language Circle: Journal of Language and Literature, 12(1), 103-113. 
